DOI: https://doi.org/10.15407/techned2022.01.025

\title{
OBSERVER-BASED SPEED ESTIMATION FOR VECTOR CONTROLLED INDUCTION MOTORS
}

\author{
S. Peresada ${ }^{1^{*}}$, Y. Nikonenko ${ }^{1^{* *}}$, S. Kovbasa ${ }^{1^{* * * *}}$, D. Rodkin ${ }^{1^{* * * *}}$, O. Kiselychnyk ${ }^{2 * * * * *}$ \\ ${ }^{1}$ National Technical University of Ukraine "Igor Sikorsky Kyiv Polytechnic Institute", \\ Peremohy av. 37, Kyiv, 03056, Ukraine, \\ e-mail: sergei.peresada@gmail.com \\ ${ }^{2}$ University of Warwick \\ Coventry, CV4 7AL, United Kingdom
}

A speed observer for field-oriented controlled induction drives is presented. The proposed solution exploits the concept of the classic full-order flux observer which is adaptive to the rotor resistance variations. Due to the structural similarity of the rotor speed and active rotor resistance in motor model, the speed observer can be designed using similar structure. The observer guarantees local asymptotic estimation of the rotor fluxes, stator currents and rotor speed in all operating conditions, excluding DC stator excitation. The stability properties of the observer are studied using Lyapunov's second method. It is experimentally shown that the observer provides an acceptable dynamics of the speed estimation if speed is slowly varying. The proposed observer is suitable for the applications with medium requirements for speed regulation performance. References 13, figures 5, table 1.

Keywords: induction motor, speed observer, asymptotic stability, estimation error.

Introduction. Vector controlled induction motors (IM) are irreplaceable in industry, transport, urban engineering, et al. Standard field-oriented control-based drives require information about motor parameters, stator currents and rotor angular speed or/and position. Presence of the mechanical coordinates sensors leads to reliability deterioration and increase of the drive cost [1].

Even though presence of speed/position sensor is inevitable for high precision, low speed or position-controlled drives, there are some applications, which do not require operation at extremely low speeds or require operation in hostile environment, where sensorless field-oriented controlled IMs are beneficial [1], [2]. For such medium applications, the sensorless drives are de-facto established the industrial standard.

The basic idea for sensorless control realization is to design a speed observer first, and use the estimated value of speed instead of the real one in standard field-oriented control algorithms. The first solutions were based on Matsuse's speed observer [3], [4]. In [3] the authors design a full-order flux observer adaptive with respect to rotor resistance variations. The similar structure of observer is used for adaptive speed estimation in [4], [5]. A Kalman filter is added in [5] to improve the performance of the speed estimation. However, no rigorous stability proof was given in [3] - [5]. Speed estimation algorithms [4], [5] are based on simplified Lyapunov's analysis and hyper-stability approach. Adaptive with respect to rotor resistance variations observer [6] has similar structure to [3] however the feedback signals has been theoretically justified leading to local asymptotic stability if motor torque or flux vector modulus are non-zero. The similar approach has been used in [7] where the stator resistance estimation law is added. Alternative approach, proposed in [8], is based on the rotor flux derivative estimation and subsequent filtered integration to get the flux information. Special integrator structure has been considered to overcome the well-known drift problem.

The first theoretically proven solution of the speed sensorless control problem of induction motors is given in [9], [10]. Speed sensorless controllers guarantee the local exponential tracking of smooth speed-flux

(C) Peresada S., Nikonenko Y., Kovbasa S., Rodkin D., Kiselychnyk O., 2022

ORCID ID: *https://orcid.org/0000-0001-8948-722X; **https://orcid.org/0000-0003-2379-5566;

$* * *$ https://orcid.org/0000-0002-2954-455X; ****https://orcid.org/0000-0002-9235-2999;

$* * * * *$ https://orcid.org/0000-0001-5688-2688 
references and constant load torque rejection together with asymptotic field orientation. High-gain approach is used in [11] to achieve the speed sensorless control objectives.

The intensive overview shows that the majority of technically oriented speed sensorless control algorithms demonstrate the performances suitable for wide spectrum of technological applications even if they do not have a rigorous stability proof. Nevertheless strong stability properties of the speed estimation are required to apply a nonlinear separation principle for design of sensorless speed control systems.

The aim of this work is to design and verify a speed observer for sensorless speed control of induction motors drives that guarantees a local exponential stability and suitable for medium performance drives applications. The proposed solution is based on general structure of the adaptive observer considered in [6].

Model of induction motor and control problem statement. Under the assumptions of linear magnetic circuits and balanced operating conditions the equivalent two-phase model of the symmetrical IM, represented in the fixed stator reference frame $(a-b)[12]$, is:

$$
\begin{aligned}
& \dot{\omega}=\frac{1}{\mathrm{~J}}\left(\mathrm{~T}-\mathrm{T}_{\mathrm{L}}\right), \quad \mathrm{T}=\mu_{1}\left(\psi_{1 \mathrm{a}} \mathrm{i}_{1 \mathrm{~b}}-\psi_{1 \mathrm{~b}} \mathrm{i}_{1 \mathrm{a}}\right), \\
& \dot{\mathrm{i}}_{1 \mathrm{a}}=-\gamma_{1} \dot{\mathrm{i}}_{1 \mathrm{a}}-\omega \mathrm{i}_{1 \mathrm{~b}}+\alpha \sigma^{-1} \psi_{1 \mathrm{a}}+\sigma^{-1} \omega \psi_{1 \mathrm{~b}}+\sigma^{-1} \mathrm{u}_{1 \mathrm{a}}, \\
& \dot{\mathrm{i}}_{1 \mathrm{~b}}=-\gamma_{1} \mathrm{i}_{1 \mathrm{~b}}+\omega \mathrm{i}_{1 \mathrm{a}}+\alpha \sigma^{-1} \psi_{1 \mathrm{~b}}-\sigma^{-1} \omega \psi_{1 \mathrm{a}}+\sigma^{-1} \mathrm{u}_{1 \mathrm{~b}}, \\
& \dot{\psi}_{1 \mathrm{a}}=-\mathrm{R}_{1} \mathrm{i}_{1 \mathrm{la}}+\mathrm{u}_{1 \mathrm{a}}, \\
& \dot{\psi}_{1 \mathrm{~b}}=-\mathrm{R}_{1} \dot{\mathrm{i}}_{1 \mathrm{~b}}+\mathrm{u}_{\mathrm{lb}},
\end{aligned}
$$

where $\omega$ is the rotor speed; $\left(i_{1 a}, i_{1 b}\right),\left(\psi_{1 a}, \psi_{1 b}\right)$ denote stator current and stator flux vectors; $\left(\mathrm{u}_{1 \mathrm{a}}, \mathrm{u}_{1 \mathrm{~b}}\right)$ is the control vector. Subscripts ' $a$ ' and ' $b$ ' stand for vector components in the (a-b) reference frame; $T_{L}$ is the load torque. Positive constants related to the IM electrical and mechanical parameters are defined as follows:

$$
\alpha=\mathrm{R}_{2} / \mathrm{L}_{2} ; \beta=\mathrm{L}_{\mathrm{m}} / \sigma \mathrm{L}_{2} ; \gamma_{1}=\mathrm{R}_{1} \sigma^{-1}+\alpha\left(1+\mathrm{L}_{\mathrm{m}} \beta\right) ; \quad \sigma=\mathrm{L}_{1}-\mathrm{L}_{\mathrm{m}}^{2} / \mathrm{L}_{2} ; \mu_{1}=3 \mathrm{~L}_{\mathrm{m}} / 2 \mathrm{~L}_{2},
$$

where $\mathrm{L}_{\mathrm{m}}$ is the magnetizing inductance; $\mathrm{R}_{1}, \mathrm{~L}_{1}$ are stator resistance and inductance; $\mathrm{R}_{2}, \mathrm{~L}_{2}$ are rotor resistance and inductance; $\mathrm{J}$ is the total rotor inertia. One pole pair is assumed without loss of generality.

Let us consider the IM model (1) and assume that:

A.1. The stator currents are available from measurements.

A.2. All model parameters are exactly known and constant.

A.3. The speed $\omega$ is unknown and constant or slowly changing, i.e. $\dot{\omega} \approx 0$.

Under these assumptions, it is required to design an adaptive asymptotic observer satisfying the following control objectives:

CO.1. Local asymptotic estimation of currents and fluxes, i.e.:

$$
\lim _{\mathrm{t} \rightarrow \infty}\left(\tilde{\mathrm{i}}_{\mathrm{a}}, \tilde{\mathrm{i}}_{\mathrm{b}}, \tilde{\psi}_{\mathrm{a}}, \tilde{\psi}_{\mathrm{b}}\right)=\mathbf{0} \text {, }
$$

where $\tilde{i}_{a}=i_{1 a}-\hat{i}_{1 a}, \tilde{i}_{b}=i_{1 b}-\hat{i}_{1 b}, \quad \tilde{\psi}_{a}=\psi_{1 a}-\hat{\psi}_{1 a}, \quad \tilde{\psi}_{b}=\psi_{1 b}-\hat{\psi}_{1 b}$ denote estimation errors; $\left(\hat{i}_{1 a}, \hat{i}_{1 b}, \hat{\psi}_{1 a}, \hat{\psi}_{1 b}\right)$ are estimates of $\left(\mathrm{i}_{1 \mathrm{a}}, \mathrm{i}_{1 \mathrm{~b}}, \psi_{1 \mathrm{a}}, \psi_{1 \mathrm{~b}}\right)$.

CO.2. Local asymptotic speed estimation, i.e.:

$$
\lim _{t \rightarrow \infty} \mathrm{e}_{\omega}=0,
$$

where $\mathrm{e}_{\omega}=\omega-\hat{\omega}, \hat{\omega}$ is speed estimate.

Observer design. The proposed speed observer has structure of full-order current-flux observer [6] with known resistances, and unknown speed. It is based on the dynamics of electric subsystem only; therefore, it is a reduced-order solution with respect to the full IM model. The observer equations are the:

$$
\begin{aligned}
& \dot{\hat{\mathrm{i}}}_{1 \mathrm{a}}=-\gamma_{1} \mathrm{i}_{1 \mathrm{a}}-\hat{\omega} \hat{\mathrm{i}}_{1 \mathrm{~b}}+\alpha \sigma^{-1} \hat{\psi}_{1 \mathrm{a}}+\sigma^{-1} \hat{\omega} \hat{\psi}_{1 \mathrm{~b}}+\sigma^{-1} \mathrm{u}_{1 \mathrm{a}}+\mathrm{k}_{1} \tilde{\mathrm{i}}_{\mathrm{a}}, \\
& \hat{\hat{\mathrm{i}}}_{1 \mathrm{~b}}=-\gamma_{1} \dot{\mathrm{i}}_{1 \mathrm{~b}}+\hat{\omega} \hat{\mathrm{i}}_{1 \mathrm{a}}+\alpha \sigma^{-1} \hat{\psi}_{1 \mathrm{~b}}-\sigma^{-1} \hat{\omega} \hat{\psi}_{1 \mathrm{a}}+\sigma^{-1} \mathrm{u}_{1 \mathrm{~b}}+\mathrm{k}_{1} \tilde{\mathrm{i}}_{\mathrm{b}}, \\
& \dot{\hat{\psi}}_{1 \mathrm{a}}=-\mathrm{R}_{1} \dot{\mathrm{i}}_{1 \mathrm{a}}+\mathrm{u}_{1 \mathrm{a}}-\mathrm{k}_{2}\left(\hat{\omega} \tilde{\mathrm{i}}_{\mathrm{b}}-\alpha \tilde{\mathrm{i}}_{\mathrm{a}}\right), \\
& \dot{\hat{\psi}}_{1 \mathrm{~b}}=-\mathrm{R}_{1} \mathrm{i}_{1 \mathrm{~b}}+\mathrm{u}_{1 \mathrm{~b}}+\mathrm{k}_{2}\left(\hat{\omega} \tilde{\mathrm{i}}_{\mathrm{a}}+\alpha \tilde{\mathrm{i}}_{\mathrm{b}}\right),
\end{aligned}
$$

where $\left(\mathrm{k}_{1}, \mathrm{k}_{2}\right)>0$ are the observer tuning gains. 
From (1), (4), the estimation error dynamics is given by:

$$
\begin{aligned}
& \dot{\tilde{\mathrm{i}}}_{\mathrm{a}}=-\mathrm{k}_{1} \tilde{\mathrm{i}}_{\mathrm{a}}-\omega \tilde{\mathrm{i}}_{1 \mathrm{~b}}-\mathrm{e}_{\omega} \hat{\mathrm{i}}_{1 \mathrm{~b}}+\alpha \sigma^{-1} \tilde{\Psi}_{1 \mathrm{a}}+\sigma^{-1} \omega \tilde{\Psi}_{1 \mathrm{~b}}+\sigma^{-1} \mathrm{e}_{\omega} \hat{\Psi}_{1 \mathrm{~b}}, \\
& \tilde{\mathrm{i}}_{\mathrm{b}}=-\mathrm{k}_{1} \tilde{\mathrm{i}}_{\mathrm{b}}+\omega \tilde{\mathrm{i}}_{\mathrm{ia}}+\mathrm{e}_{\omega} \hat{\mathrm{i}}_{1 \mathrm{a}}+\alpha \sigma^{-1} \tilde{\Psi}_{1 \mathrm{~b}}-\sigma^{-1} \omega \tilde{\Psi}_{1 \mathrm{a}}-\sigma^{-1} \mathrm{e}_{\omega} \hat{\psi}_{1 \mathrm{a}}, \\
& \dot{\tilde{\Psi}}_{1 \mathrm{a}}=\mathrm{k}_{2}\left(\hat{\omega} \tilde{\mathrm{i}}_{\mathrm{b}}-\alpha \tilde{\mathrm{i}}_{\mathrm{a}}\right), \\
& \dot{\tilde{\Psi}}_{1 \mathrm{~b}}=-\mathrm{k}_{2}\left(\hat{\omega} \tilde{\mathrm{i}}_{\mathrm{a}}+\alpha \tilde{\mathrm{i}}_{\mathrm{b}}\right) .
\end{aligned}
$$

In order to analyze the stability properties of proposed observer (4), the following candidate Lyapunov function is defined:

$$
\mathrm{V}=\frac{1}{2}\left(\tilde{\mathrm{i}}_{\mathrm{a}}^{2}+\tilde{\mathrm{i}}_{\mathrm{b}}^{2}+\frac{1}{\sigma \mathrm{k}_{2}}\left(\tilde{\psi}_{1 \mathrm{a}}^{2}+\tilde{\psi}_{1 \mathrm{~b}}^{2}\right)+\frac{1}{\gamma_{\omega}} \mathrm{e}_{\omega}^{2}\right)>0
$$

where $\gamma_{\omega}>0$ is constant tuning gain.

Taking into account that $\hat{\omega}=\omega-\mathrm{e}_{\omega}$, the time derivative of (6) along the trajectories of (5) is:

$$
\dot{V}=-\mathrm{k}_{1}\left(\tilde{\mathrm{i}}_{\mathrm{a}}^{2}+\tilde{\mathrm{i}}_{\mathrm{b}}^{2}\right)+\left(\left(-\hat{\mathrm{i}}_{1 \mathrm{~b}}+\sigma^{-1} \hat{\psi}_{1 \mathrm{~b}}\right) \tilde{\mathrm{i}}_{\mathrm{a}}+\left(\hat{\mathrm{i}}_{1 \mathrm{a}}-\sigma^{-1} \hat{\psi}_{1 \mathrm{a}}\right) \tilde{\mathrm{i}}_{\mathrm{b}}+\gamma_{\omega}^{-1} \dot{\mathrm{e}}_{\omega}\right) \mathrm{e}_{\omega}+\sigma^{-1}\left(-\tilde{\mathrm{i}}_{\mathrm{b}} \tilde{\psi}_{1 \mathrm{a}}+\tilde{\mathrm{i}}_{\mathrm{a}} \tilde{\psi}_{1 \mathrm{~b}}\right) \mathrm{e}_{\omega} .
$$

From (7) the estimation algorithm is expressed as:

$$
\dot{\mathrm{e}}_{\omega}=-\gamma_{\omega}\left(\left(-\hat{\mathrm{i}}_{1 \mathrm{~b}}+\sigma^{-1} \hat{\psi}_{1 \mathrm{~b}}\right) \tilde{\mathrm{i}}_{\mathrm{a}}+\left(\hat{\mathrm{i}}_{\mathrm{la}}-\sigma^{-1} \hat{\psi}_{1 \mathrm{a}}\right) \tilde{\mathrm{i}}_{\mathrm{b}}\right),
$$

leading to derivative of Lyapunov function:

$$
\dot{\mathrm{V}}=-\mathrm{k}_{1}\left(\tilde{\dot{\mathrm{i}}}_{\mathrm{a}}^{2}+\tilde{\mathrm{i}}_{\mathrm{b}}^{2}\right)+\sigma^{-1}\left(-\tilde{\mathrm{i}}_{\mathrm{b}} \tilde{\Psi}_{1 \mathrm{a}}+\tilde{\mathrm{i}}_{\mathrm{a}} \tilde{\Psi}_{1 \mathrm{~b}}\right) \mathrm{e}_{\omega} .
$$

Considering that the terms $\tilde{\mathrm{i}}_{\mathrm{b}} \tilde{\Psi}_{1 \mathrm{a}} \mathrm{e}_{\omega}$ and $\tilde{\mathrm{i}}_{\mathrm{a}} \tilde{\Psi}_{1 \mathrm{~b}} \mathrm{e}_{\omega}$ in the vicinity of equilibrium point are negligibly small, equation (9) becomes:

$$
\dot{\mathrm{V}}=-\mathrm{k}_{1}\left(\tilde{\mathrm{i}}_{\mathrm{a}}^{2}+\tilde{\mathrm{i}}_{\mathrm{b}}^{2}\right)<0 .
$$

From (6), (10), it follows that $\left(\tilde{\mathrm{i}}_{\mathrm{la}}, \tilde{\mathrm{i}}_{1 \mathrm{~b}}, \tilde{\psi}_{\mathrm{la}}, \tilde{\psi}_{1 \mathrm{~b}}, \mathrm{e}_{\omega}\right)$ are bounded $\forall \mathrm{t} \geq 0$. From (5), (8) it goes that $\left(\hat{\mathrm{i}}_{1 \mathrm{a}}, \hat{\mathrm{i}}_{\mathrm{lb}}, \hat{\psi}_{\mathrm{a}}, \hat{\psi}_{\mathrm{b}}, \hat{\omega}, \dot{\tilde{\mathrm{i}}}_{\mathrm{la}}, \dot{\tilde{\mathrm{i}}}_{\mathrm{b}}, \dot{\tilde{\Psi}}_{\mathrm{a}}, \dot{\tilde{\Psi}}_{\mathrm{b}}, \dot{\mathrm{e}}_{\omega}\right)$ are bounded too, and $\left(\tilde{\mathrm{i}}_{\mathrm{la}}, \tilde{\mathrm{i}}_{\mathrm{lb}}, \tilde{\psi}_{1 \mathrm{a}}, \tilde{\Psi}_{1 \mathrm{~b}}, \mathrm{e}_{\omega}\right)$ are uniformly continuous. Since $V(t) \leq V(0) / k_{1}$, then $\tilde{\mathrm{i}}_{1 a}, \tilde{\mathrm{i}}_{1 b}$ are square integrable signals and, therefore, according to Barbalat's lemma [13], it results that $\lim _{\mathrm{t} \rightarrow \infty}\left(\tilde{\mathrm{i}}_{\mathrm{la}}, \tilde{\mathrm{i}}_{\mathrm{lb}}\right)=\mathbf{0}$.

Complete equations of estimation error dynamics are given by (5), (8), and the speed estimation law is:

$$
\dot{\hat{\omega}}=-\dot{\mathrm{e}}_{\omega}=\gamma_{\omega}\left(\left(-\hat{\mathrm{i}}_{1 \mathrm{~b}}+\sigma^{-1} \hat{\psi}_{1 \mathrm{~b}}\right) \tilde{\mathrm{i}}_{\mathrm{a}}+\left(\hat{\mathrm{i}}_{\mathrm{la}}-\sigma^{-1} \hat{\psi}_{1 \mathrm{a}}\right) \tilde{\mathrm{i}}_{\mathrm{b}}\right) \text {. }
$$

Partially linearized system (5), (8) with neglected quadratic components $\left(e_{\omega} \tilde{i}_{b}, e_{\omega} \tilde{i}_{a}\right)^{T}$ in (5) can be represented in the following standard form:

$$
\begin{aligned}
& \dot{\tilde{\mathbf{i}}}=\mathbf{A} \tilde{\mathbf{i}}+\mathbf{W}(\mathrm{t}) \tilde{\mathbf{z}}, \\
& \dot{\tilde{\mathbf{z}}}=-\boldsymbol{\Gamma} \mathbf{W}^{\mathrm{T}}(\mathrm{t}) \tilde{\mathbf{i}},
\end{aligned}
$$

$$
\begin{aligned}
& \text { where } \quad \tilde{\mathbf{i}}=\left(\tilde{\mathrm{i}}_{\mathrm{a}}, \tilde{\mathrm{i}}_{\mathrm{b}}\right)^{\mathrm{T}}, \quad \tilde{\mathbf{z}}=\left(\tilde{\psi}_{1 \mathrm{a}}, \tilde{\Psi}_{1 \mathrm{~b}}, \mathrm{e}_{\omega}\right)^{\mathrm{T}}, \quad \mathbf{A}=\left[\begin{array}{cc}
-\mathrm{k}_{1} & -\omega \\
\omega & -\mathrm{k}_{1}
\end{array}\right], \quad \boldsymbol{\Gamma}=\operatorname{diag}\left(\mathrm{k}_{2}, \mathrm{k}_{2}, \gamma_{\omega}\right), \\
& \mathbf{W}(\mathrm{t})=\left[\begin{array}{ccc}
\alpha & \omega & \hat{\mathrm{i}}_{1 \mathrm{~b}}-\sigma^{-1} \hat{\psi}_{1 \mathrm{~b}} \\
-\omega & \alpha & -\hat{\mathrm{i}}_{1 \mathrm{a}}+\sigma^{-1} \hat{\psi}_{1 \mathrm{a}}
\end{array}\right] .
\end{aligned}
$$


System (12) has standard form considered in persistency of excitation lemma [13]. Since $\mathbf{A}$ is Hurwitz, $\mathbf{W}(\mathrm{t}), \dot{\mathbf{W}}(\mathrm{t})$ are bounded and if positive constant $\mathrm{T}$ exist, so that the conditions of persistency of excitation

$$
\int_{t}^{t+T} \mathbf{W}^{\mathrm{T}}(\tau) \mathbf{W}(\tau) \mathrm{d} \tau>0
$$

are met $\forall \mathrm{t} \geq 0$, then $(\tilde{\mathbf{i}}, \tilde{\mathbf{z}})=\mathbf{0}$ is globally exponentially stable equilibrium point for partially linearized system (12) and therefore system (5), (8) is locally exponentially stable.

For the use of the observer (4), (11) as part of the control systems, it is beneficial to made one modification to compensate for the derivative of reference speed trajectory, such that (11) becomes

$$
\dot{\hat{\omega}}=\gamma_{\omega}\left(\left(-\hat{i}_{1 b}+\sigma^{-1} \hat{\psi}_{1 b}\right) \tilde{\mathrm{i}}_{\mathrm{a}}+\left(\hat{\mathrm{i}}_{1 \mathrm{a}}-\sigma^{-1} \hat{\psi}_{1 \mathrm{a}}\right) \tilde{\mathrm{i}}_{\mathrm{b}}\right)+\dot{\omega}^{*}
$$

where $\dot{\omega}^{*}$ is the first derivative of speed reference $\omega^{*}$.

Simulation and experimental study. Proposed observer has been tested in an open-loop operation in which the observer has no influence on control algorithm. The indirect field-oriented speed controller based on speed measurement, which was applied to a motor in this study, is given in [12].

Experimental set-up. The proposed adaptive speed observer (4), (11) has been tested by means of simulations and experiments using a $0.75-\mathrm{kW}$ induction motor whose rated data are reported in Table.

\begin{tabular}{|l|c||l|l||l|l|}
\hline \multicolumn{1}{|c|}{ Parameter } & Value & \multicolumn{1}{|c|}{ Parameter } & Value & Parameter & Value \\
\hline Rated power $\mathrm{P}_{2 \mathrm{n}}, \mathrm{kW}$ & 0.75 & Stator resistance $\mathrm{R}_{1}, \mathrm{Ohm}$ & 11 & $\alpha, \mathrm{s}^{-1}$ & 5.9 \\
\hline Rated torque $\mathrm{T}_{\mathrm{n}}, \mathrm{Nm}$ & 2.5 & Rotor resistance $\mathrm{R}_{2}, \mathrm{Ohm}$ & 5.8 & $\beta, \mathrm{H}^{-1}$ & 12.2 \\
\hline Total rotor inertia $\mathrm{J}, \mathrm{kgm}^{2}$ & 0.003 & Stator inductance $\mathrm{L}_{1}, \mathrm{H}$ & 0.95 & $\gamma, \mathrm{s}^{-1}$ & 206 \\
\hline Pole pairs number $\mathrm{p}_{\mathrm{n}}$ & 1 & Rotor inductance $\mathrm{L}_{2}, \mathrm{H}$ & 0.95 & $\sigma, \mathrm{H}$ & 0.08 \\
\hline Viscous friction coefficient $\mathrm{v}, \mathrm{Nm} /(\mathrm{rad} / \mathrm{s})$ & 0.0015 & Magnetizing inductance $\mathrm{L}_{\mathrm{m}}, \mathrm{H}$ & 0.91 & $\mu,\left(\mathrm{kgm}^{2}\right)^{-1}$ & 400 \\
\hline
\end{tabular}

The experiments are carried out using the Rapid Prototyping Station (RPS) shown in Fig. 1. The RPS includes: IM and a loading DC motor which operates in a torque control mode; three-phase PWM controlled inverter, operated at $10 \mathrm{kHz}$ switching frequency; DSP TMS320F28335 controller which performs data acquisition, implements control algorithms with programmable tracing of selected variables; personal computer for processing, programming, interactive oscilloscope, data acquisition, etc. The motor speed is measured by a $1024 \mathrm{pulse} /$ revolution optical encoder. The sampling time is $200 \mu \mathrm{s}$.

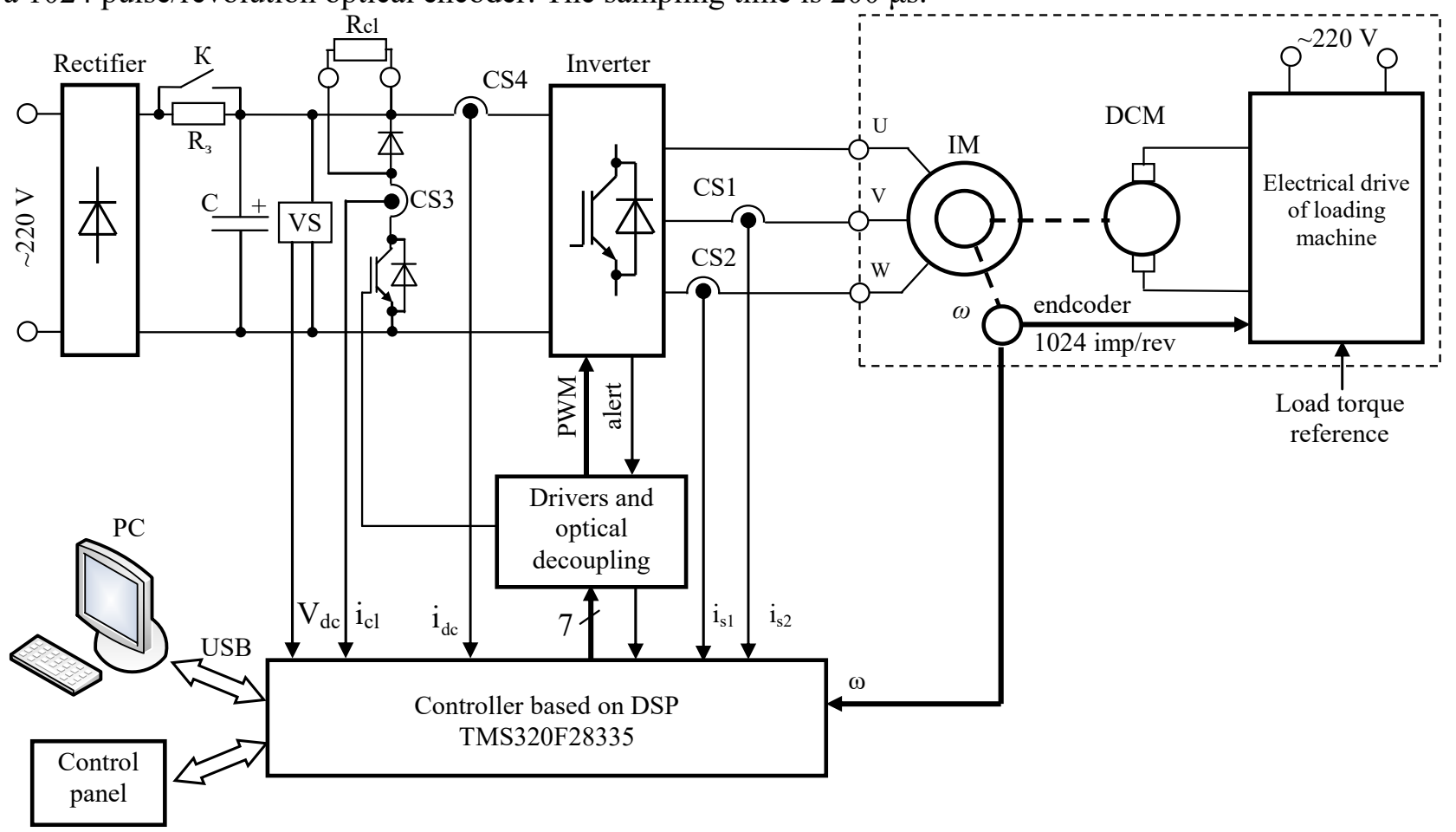

Fig. 1 

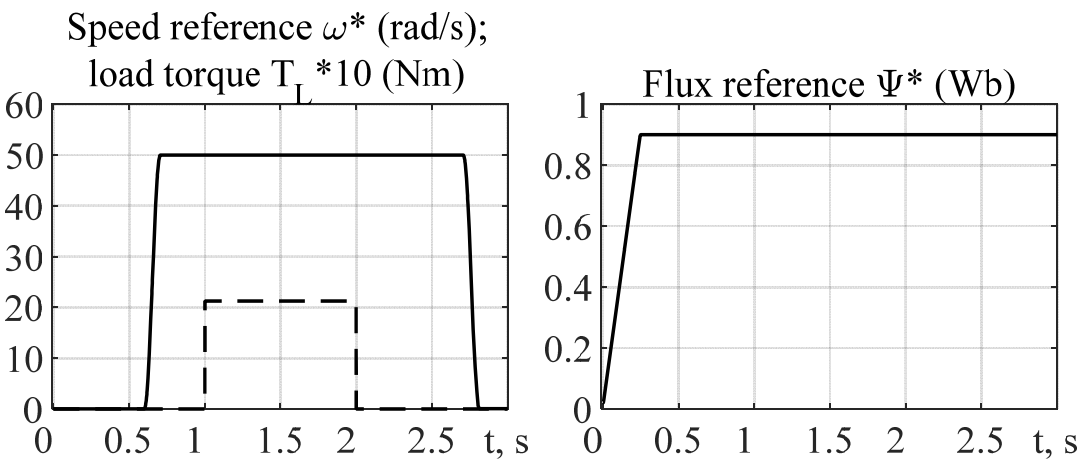

Fig. 2

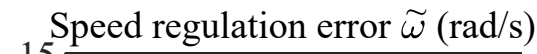

Speed estimation error e $(\mathrm{rad} / \mathrm{s})$
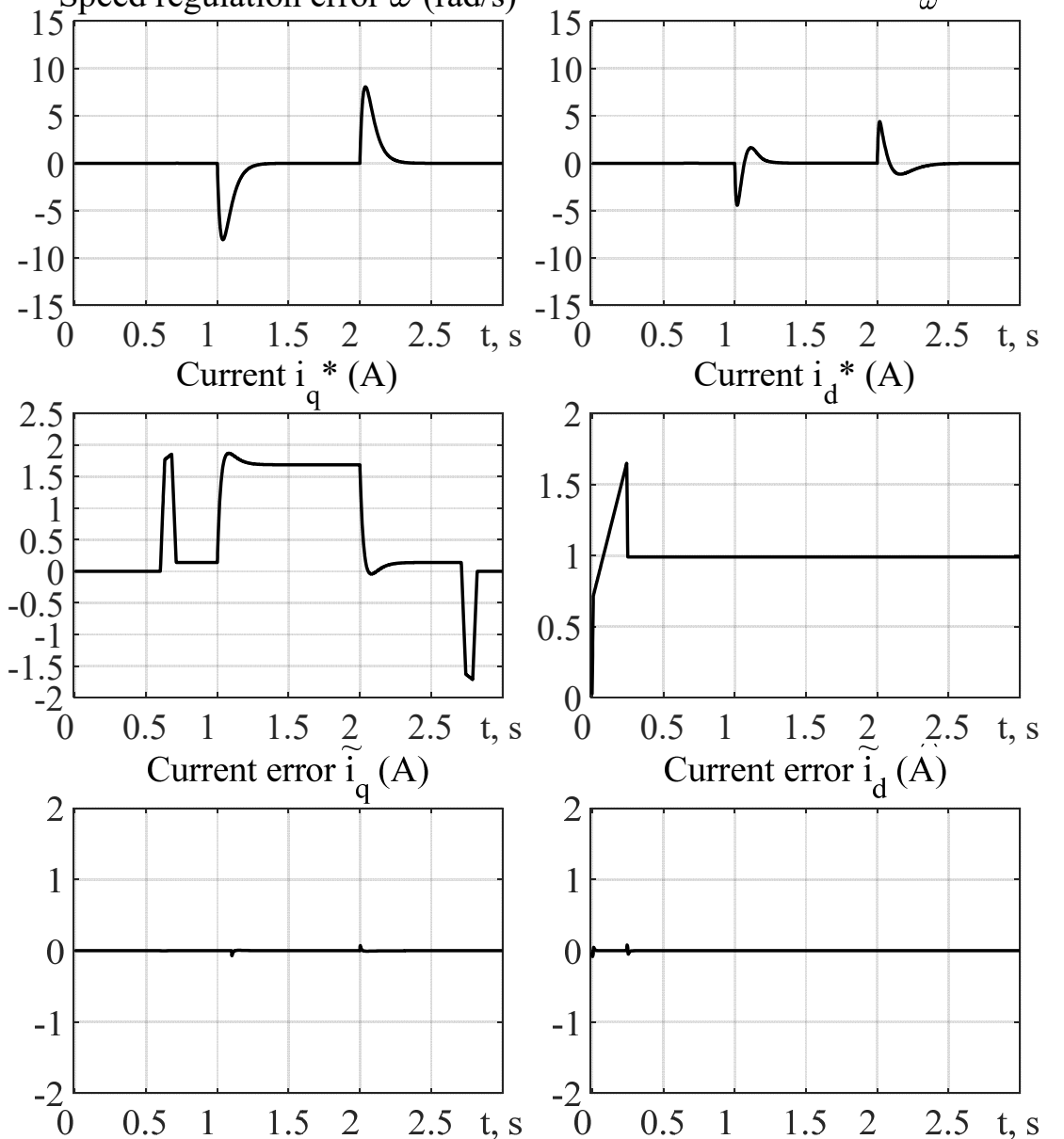

Current estimation error $\widetilde{i}_{a}(A)$
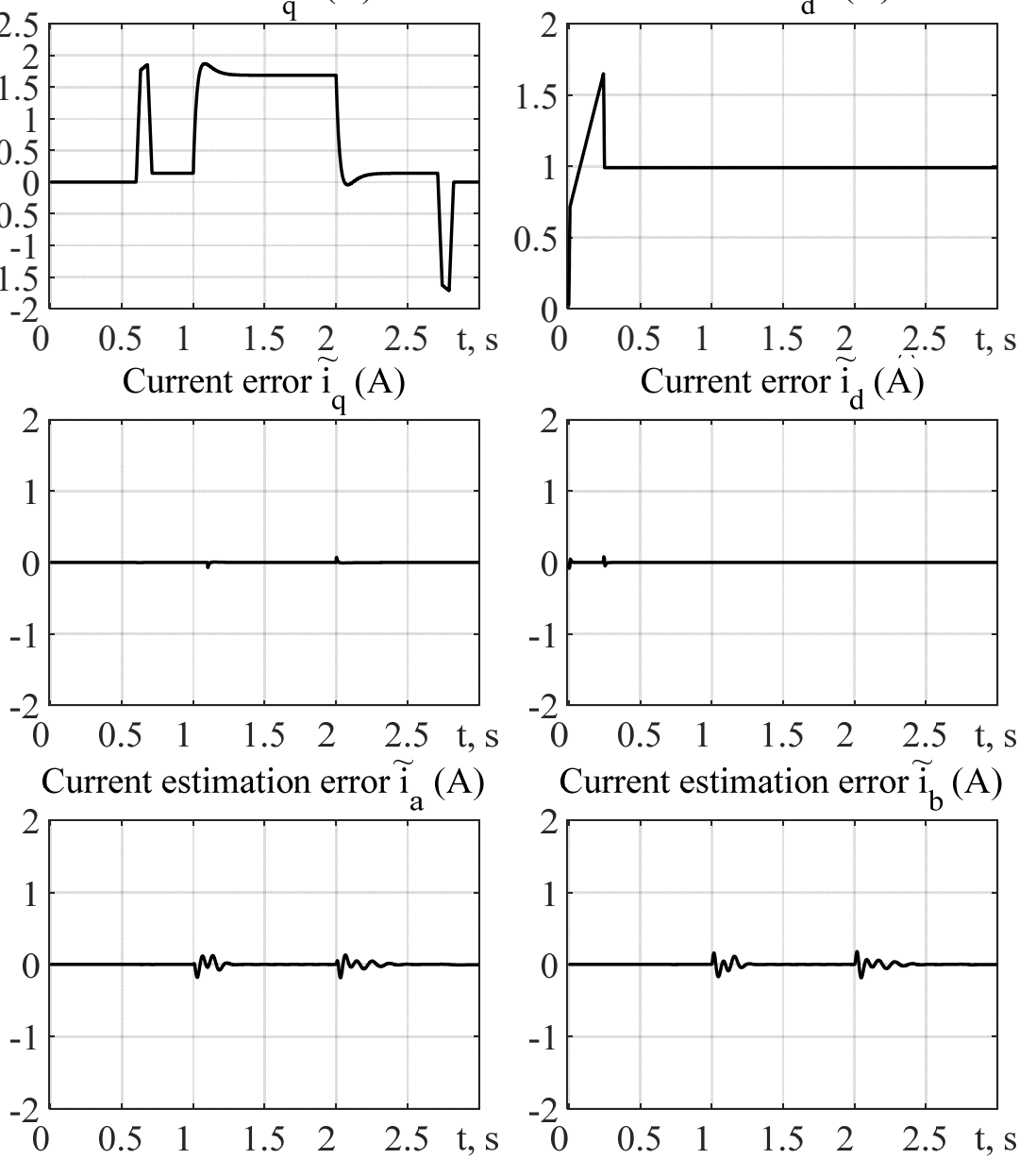
Current error $\widetilde{\mathrm{i}}_{\mathrm{d}}(\mathrm{A})$

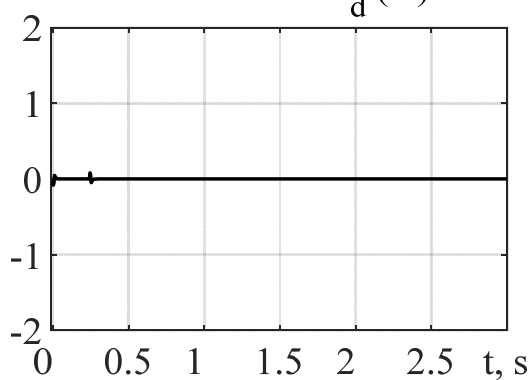

Current estimation error $\widetilde{\mathrm{i}}_{\mathrm{b}}$ (A)

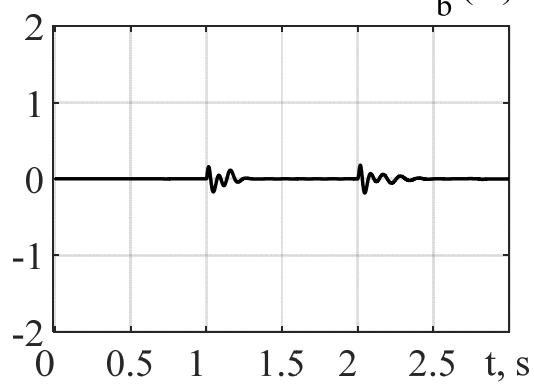

Fig. 3
Observer and controller

tuning. Observer parameters have been selected according to the practical viewpoint, that the timescale separation between speed regulation dynamics and speed estimation dynamics is achieved. Some implementation aspects, such as robustness with respect to parameter uncertainties and unmodelled dynamics, sensitivity with respect to measurement noise, issues related to discretetime implementation of the algorithm, have been taken into account in a heuristic way, performing some simulations and/or experiments in order to refine the controller tuning.

The following speed-flux controller [12] gains have been chosen for all simulations and experiments. The speed controller gains are set at: proportional gain $\mathrm{k}_{\omega}=50$, integral gain $\mathrm{k}_{\omega \mathrm{i}}=\mathrm{k}_{\omega}^{2} / 4$. Current controller gains have been set at: proportional gains $\mathrm{k}_{\mathrm{id}}=\mathrm{k}_{\mathrm{iq}}=500$, integral gains $\mathrm{k}_{\mathrm{iid}}=\mathrm{k}_{\mathrm{iiq}}=\left(\mathrm{k}_{\mathrm{id}}+\gamma\right)^{2} / 2$. The tuning gains of the speed observer are selected as $k_{1}=200, \gamma_{\omega}=100$, $\mathrm{k}_{2}=0.24$. All initial conditions are zero, except for the flux reference $\psi^{*}(0)=0.02 \mathrm{~Wb}$.

Operating sequences.

The flux and speed reference trajectories adopted in the experiments are presented in Fig. 2 using solid lines; dashed line in the same figure represents the load torque profile.

The operating sequence of the performed tests is the following:

1. The machine is excited during the initial time interval 0 $0.25 \mathrm{~s}$ using a flux reference tra-

jectory starting at $\psi^{*}(0)=0.02 \mathrm{~Wb}$ and reaching the motor rated value of $0.9 \mathrm{~Wb}$.

2. The unloaded motor is required to track the speed reference trajectory characterized by the following phases: starting from $t=0.6 \mathrm{~s}$ with zero initial value, speed reference trajectory reaches $50 \mathrm{rad} / \mathrm{s}(15 \%$ of 
rated) at $\mathrm{t}=0.65 \mathrm{~s}$; from this time up to $\mathrm{t}=2.7 \mathrm{~s}$ constant speed is imposed; from $\mathrm{t}=2.7 \mathrm{~s}$ the motor is required to stop at zero speed reference. Tracking of the speed reference trajectory requires rated motor torque.

3 . During the time interval with constant speed reference, a step load torque, equal to $90 \%$ of the motor rated value $(2.2 \mathrm{Nm})$, is applied and removed.

Simulation and experimental results. The transients reported in Fig. 3, Fig. 4 show the steady-state and dynamic performance during the test in simulation and experiment, respectively. The transient performance is characterized by a maximum speed tracking error of about $8 \mathrm{rad} / \mathrm{s}$ during load torque rejection transients. Speed estimation error dynamics is faster than the speed tracking error dynamics, confirming that time-scale separation is achieved. Negligible current estimation errors are present during the experiments. Simulation transients, reported in Fig. 3, are close to the experimental results in Fig. 4.

Note that in simulation tests, zero speed estimation error is achieved during steady-state conditions and during speed reference variation, while speed estimation error is not null in the experiments. This is mainly due to IM parameters uncertainties and inverter non-idealities such as dead-time effect and voltage commutations. In Fig. 3 stator current estimation errors are also reported, showing that asymptotic estimation is achieved.

A second set of experiments has been performed to test the proposed solution with changing speed estimation gain $\gamma_{\omega}$, as shown in Fig. 5. As it is well-known [9], observer must ensure faster error dynamics than the regulation error dynamics. On the other hand, too high value of estimation gain will lead to high sensitivity with respect to measurement noise. Tuning with $\gamma_{\omega}=100$ was defined as acceptable.
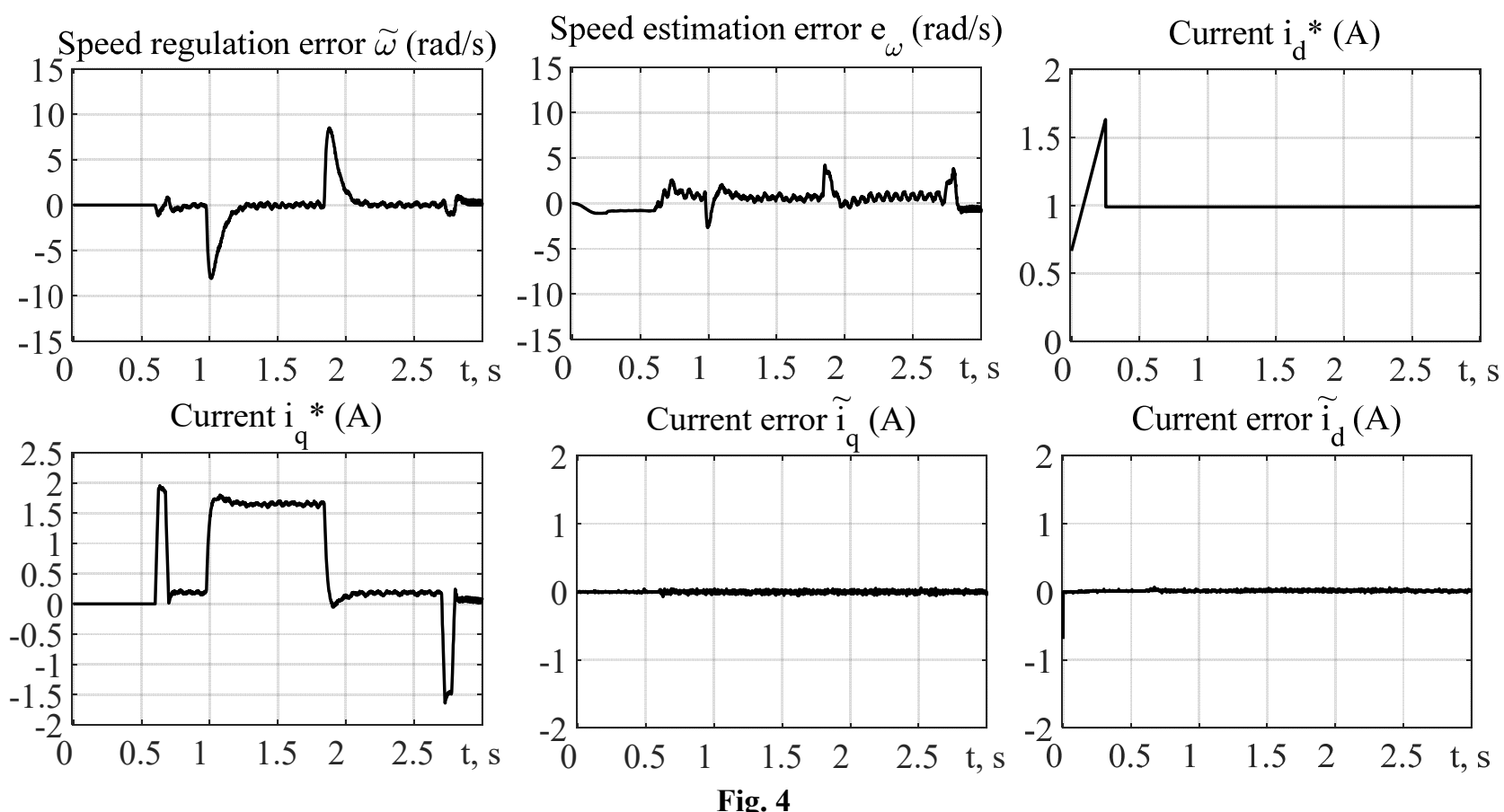

Fig. 4

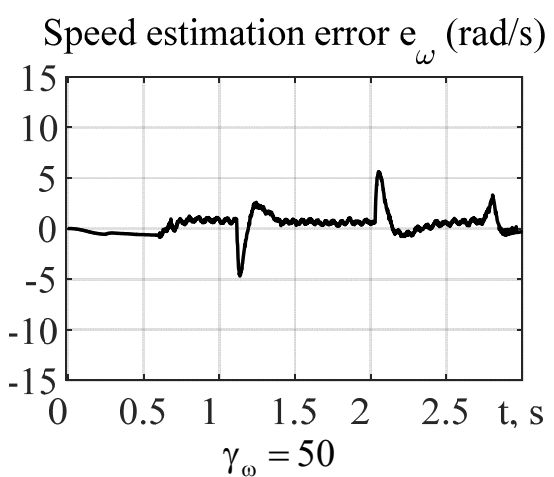

$\boldsymbol{a}$

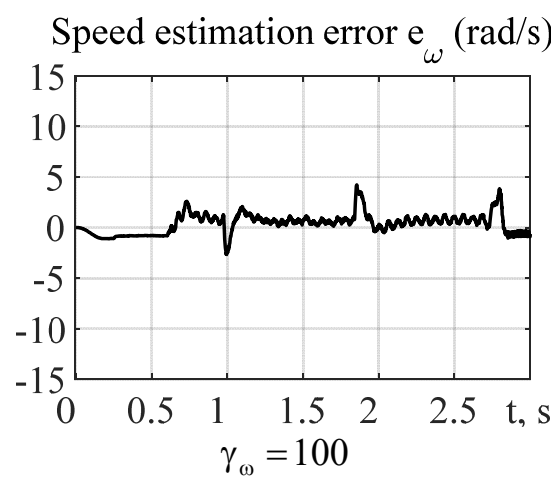

$b$

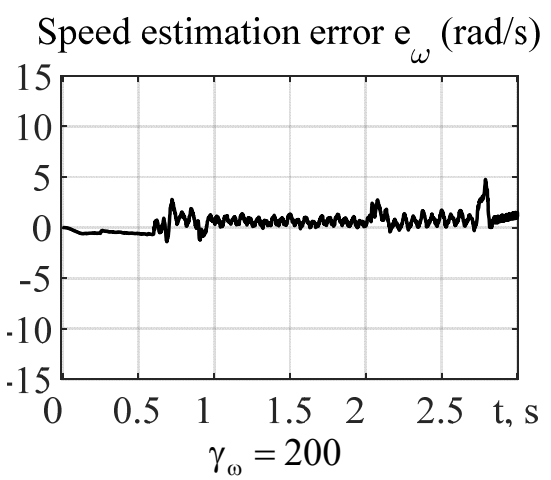

c

Fig. 5 
Conclusions. A novel speed estimation algorithm for induction motors was designed based on structure of the full-order current-flux observer. The observer guarantees a local asymptotic exponential stability of the speed estimation. Experiments and simulations in typical operating conditions demonstrate that acceptable dynamic performance of estimation error during speed and flux tracking including load torque rejection is achieved. Preliminary investigations show that implementation of the observer in the closed-loop speed control system provides satisfactory results.

1. Xu D., Wang B., Zhang G., Wang G., Yu Y. A review of sensorless control methods for AC motor drives. CES Transactions on Electrical Machines and Systems. 2018. Vol. 2. No 1. Pp. 104-115. DOI: https://doi.org/10.23919/TEMS.2018.8326456

2. Pacas M. Sensorless drives in industrial applications. IEEE Industrial Electronics Magazine. June 2011. Vol. 5. No 2. Pp. 16-23. DOI: https://doi.org/10.1109/MIE.2011.941125

3. Kubota H., Matsuse K., Nakano T. DSP-based speed adaptive flux observer of induction motor. IEEE Transactions on Industry Applications. 1993. Vol. 29. No 2. Pp. 344-348. DOI: https://doi.org/10.1109/28.216542

4. Kubota H., Matsuse K., Nakano T. New adaptive flux observer of induction motor for wide speed range motor drives. Proc. Annual Conference IEEE Industrial Electronics Society IECON90. California, USA, November 27-30, 1990. Pp. 921-926. DOI: https://doi.org/10.1109/IECON.1990.149262

5. Lee C.-M., Chen C.-L. Observer-based speed estimation method for sensorless vector control of induction motors. IEE Proceedings - Control Theory and Applications. 1998. Vol. 145. No 3. Pp. 359-363. DOI: https://doi.org/10.1049/ip-cta:19983251

6. Peresada S.M., Bovkunovich V.S., Kovbasa S.N. Adaptive Matsuse observer: a new synthesis, which guarantees asymptoticity of flux linkage vector estimation and active rotor resistance of asynchronous motor. Tekhnichna Elektrodynamika. 2010. No 3. Pp. 28-32. (Rus)

7. Verrelli C.M., Savoia A., Mengoni M., Marino R., Tomei P., Zarri L. On-line identification of winding resistances and load torque in induction machines. IEEE Transactions on Control Systems Technology. 2014. Vol. 22. No 4. Pp. 1629-1637. DOI: https://doi.org/10.1109/TCST.2013.2285604

8. Wang Z.S., Ho S.L., Cheng E.K.W. A novel observer based flux estimation for speed sensorless DFO control of induction machine. Electric power components and systems. 2005. Vol. 33. Pp. 333-348. DOI: https://doi.org/10.1080/15325000590474681

9. Montanari M., Peresada S., Tilli A. A speed-sensorless indirect field-oriented control for induction motors based on high gain speed estimation. Automatica. 2006. Vol. 42. Pp. 1673-1650. DOI: https://doi.org/10.1016/j.automatica.2006.05.021

10. Montanari M., Peresada S.M., Rossi C., Tilli A. Speed sensorless control of induction motors based on a reducedorder adaptive observer. IEEE Transactions on Control Systems Technology. 2007. Vol. 15. No 6. Pp. 1049-1064. DOI: https://doi.org/10.1109/TCST.2007.899714

11. Khalil H.K., Strangas E.G., Jurkovic S. Speed observer and reduced nonlinear model for sensorless control of induction motors. IEEE Transactions on Control Systems Technology. 2009. Vol. 17. No 2. Pp. 327-339. DOI: https://doi.org/10.1109/TCST.2008.2000977

12. Peresada S.M. A generalized theory of indirect vector control by an asynchronous motor. Part II. Synthesis of an algorithm for working out the flow modulus and angular velocity. Tekhnichna Elektrodynamika. 1999. No 4. Pp. 2631. (Rus)

13. Narendra K.S., Annaswamy A.M. Stable adaptive systems. New Jersey, Englewood Cliffs: Prentice Hall, 1989. 480 p.

\author{
УДК 681.5: 62-83
}

ОЦІНЮВАННЯ ШВИДКОСТІ ВЕКТОРНО-КЕРОВАНИХ АСИНХРОННИХ ДВИГУНІВ НА ОСНОВІ СПОСТЕРІГАЧА С.М. Пересада ${ }^{1}$, докт. техн. наук, С.О. Ніконенко ${ }^{1}$, С.М. Ковбаса ${ }^{1}$, докт. техн. наук, Д.І. Родькін ${ }^{1}$,
О.І. Кіселичник ${ }^{2}$

${ }^{1}$ НТУ Украӥни «Київський політехнічний інститут ім. Ігоря Сікорського», пр. Перемоги, 37, Київ, 03056, Україна,

e-mail: $\quad$ sergei.peresada@gmail.com

${ }^{2}$ Університет Ворика,

Ковентрі, CV4 7AL, Великобританія

У роботі представлено спостерігач швидкості для систем векторного керування асинхронними двигунами. Запропоноване рімення засноване на принципі побудови класичного спостерігача потокозчеплення повного 
порядку, який є адаптивним до варіацій активного опору ротора. Завдяки структурній подібності швидкості ротора і активного опору ротора в моделі асинхронного двигуна, спостерігач швидкості може бути спроектований на основі аналогічної структури. Розроблений спостерігач гарантує локальне асимптотичне оцінювання потокозчеплень ротора, струмів статора $і$ швидкості ротора в усіх робочих режимах за винятком збудження двигуна постійним струмом. Стійкість процесу очінювання спостерігача доведено на основі другого методу Ляпунова. Результати експериментального дослідження свідчать, щуо спостерігач забезпечує достатній рівень показників якості динаміки очінювання швидкості, якщо швидкість змінюється повільно. 3 пропонований спостерігач може бути використаний для застосувань із середніми вимогами до якості регулювання швидкості. Бібл. 13, рис. 5, табл. 1.

Ключові слова: асинхронний двигун, спостерігач швидкості, асимптотична стійкість, похибка оцінювання.

1. Xu D., Wang B., Zhang G., Wang G., Yu Y. A review of sensorless control methods for AC motor drives. CES Transactions on Electrical Machines and Systems. 2018. Vol. 2. No 1. Pp. 104-115. DOI: https://doi.org/10.23919/TEMS.2018.8326456

2. Pacas M. Sensorless drives in industrial applications. IEEE Industrial Electronics Magazine. June 2011. Vol. 5. No 2. Pp. 16-23. DOI: https://doi.org/10.1109/MIE.2011.941125

3. Kubota H., Matsuse K., Nakano T. DSP-based speed adaptive flux observer of induction motor. IEEE Transactions on Industry Applications. 1993. Vol. 29. No 2. Pp. 344-348. DOI: https://doi.org/10.1109/28.216542

4. Kubota H., Matsuse K., Nakano T. New adaptive flux observer of induction motor for wide speed range motor drives. Proc. Annual Conference IEEE Industrial Electronics Society IECON90. California, USA, November 27-30, 1990. Pp. 921-926. DOI: https://doi.org/10.1109/IECON.1990.149262

5. Lee C.-M., Chen C.-L. Observer-based speed estimation method for sensorless vector control of induction motors. IEE Proceedings - Control Theory and Applications. 1998. Vol. 145. No 3. Pp. 359-363. DOI: https://doi.org/10.1049/ip-cta:19983251

6. Пересада С.М., Бовкунович В.С., Ковбаса С.Н., Адаптивный наблюдатель Матсусе: новый синтез, гарантирующий асимптотичность оценивания вектора потокосцепления и активного сопротивления ротора асинхронного двигателя. Технічна електродинаміка. 2010. № 3. С. 28-32. URL: http://previous.techned.org.ua/article/10-3/st5.pdf (дата звернення 24.10.2021)

7. Verrelli C.M., Savoia A., Mengoni M., Marino R., Tomei P., Zarri L. On-line identification of winding resistances and load torque in induction machines. IEEE Transactions on Control Systems Technology. 2014. Vol. 22. No 4. Pp. 1629-1637. DOI: https://doi.org/10.1109/TCST.2013.2285604

8. Wang Z.S., Ho S.L., Cheng E.K.W. A novel observer based flux estimation for speed sensorless DFO control of induction machine. Electric power components and systems. 2005. Vol. 33. Pp. 333-348. DOI: https://doi.org/10.1080/15325000590474681

9. Montanari M., Peresada S., Tilli A. A speed-sensorless indirect field-oriented control for induction motors based on high gain speed estimation. Automatica. 2006. Vol. 42. Pp. 1673-1650. DOI: https://doi.org/10.1016/j.automatica.2006.05.021

10. Montanari M., Peresada S.M., Rossi C., Tilli A. Speed sensorless control of induction motors based on a reducedorder adaptive observer. IEEE Transactions on Control Systems Technology. 2007. Vol. 15. No 6. Pp. $1049-1064$. DOI: https://doi.org/10.1109/TCST.2007.899714

11. Khalil H.K., Strangas E.G., Jurkovic S. Speed observer and reduced nonlinear model for sensorless control of induction motors. IEEE Transactions on Control Systems Technology. 2009. Vol. 17. No 2. Pp. 327-339. DOI: https://doi.org/10.1109/TCST.2008.2000977

12. Пересада С.М. Обобщенная теория косвенного векторного управления асинхронным двигателем. Часть II. Синтез алгоритма отработки модуля потока и угловой скорости. Технічна електродинаміка. 1999. № 4. С. 26-31.

13. Narendra K.S., Annaswamy A.M. Stable adaptive systems. New Jersey, Englewood Cliffs: Prentice Hall, 1989. 480 p.

Надйшла 29.10.2021 